\title{
The Work of Ho Chi Minh Communist Youth Union at the Grassroots Level
}

\author{
Dinh Van Chi \\ Faculty of Party Building, Ho Chi Minh City Cadre Academy, Ho Chi Minh City, Vietnam
}

Email address:

dinhvanchi84@gmail.com

\section{To cite this article:}

Dinh Van Chi. The Work of Ho Chi Minh Communist Youth Union at the Grassroots Level. Advances in Sciences and Humanities. Vol. 7, No. 2, 2021, pp. 13-18. doi: 10.11648/j.ash.20210702.11

Received: March 20, 2021; Accepted: April 6, 2021; Published: April 13, 2021

\begin{abstract}
This study focuses on clarifying the activities of the Ho Chi Minh Communist Youth Union at the grassroots level, clarifying the views and practical activities of this organization. With this goal, the author gives 2 hypotheses: 1 / Many views have shown awareness of the Ho Chi Minh Communist Youth Union's importance in the cause of national defense and development. 2 / The Ho Chi Minh Communist Youth Union at the grassroots level organizes activities, creates an educational environment, trains union members and young people to contribute to the implementation of political, economic, cultural social, national defense and security tasks of localities; represent, care for and protect the legitimate rights and interests of cadres, union members and children; coordinate with the authorities, unions and socio-economic organizations to do well the youth work, pay attention to the development of the Youth Union, actively build the base of groups, associations, and teams in residential areas, participate building and defending the Party and government. To achieve research goals and hypotheses, the author uses scientific research methods such as analysis and synthesis, interpretation and induction, abstraction and generalization, logic and history, history and compare to come to general conclusions and conclusions that research towards the work of the Ho Chi Minh Communist Youth Union at grassroots level.
\end{abstract}

Keywords: Work, Communist Youth Union, Grassroots Level

\section{Introduction}

The requirements of the period of accelerating industrialization and modernization of the country, the process of international integration, and the rapid change of the youth situation requires strengthening the Party's leadership over youth work to foster and promote the highest level of the youth's role and strength in the cause of building and defending the Socialist Vietnam Fatherland. The Ho Chi Minh Communist Youth Union at the grassroots level plays an important role in guiding the Youth to follow the Party's lines, undertakings and policies, and the laws of the State.

The Ho Chi Minh Communist Youth Union was trained through building and training activities, and maturing through the revolutionary struggles. The Youth Union gathered a large number of young people to promote revolutionary heroism, contribute greatly to the cause of national liberation, reunification, construction, and defense. Entering a new period, the Youth Union will continue to promote its precious national traditions and good nature, building a generation of the Vietnamese Youth with patriotism and national resilience; being steadfast in the ideals of national independence and socialism, revolutionary morality, and a sense of law observance, have ability and bravery in international integration; have health, knowledge, skills and industrial manners in collective labor, becoming good citizens of the country; impulsive and creative to master advanced science and technology.

Ho Chi Minh Communist Youth Union operates under the ideological foundation and principles of the Communist Party of Vietnam, taking Marxism Leninism and Ho Chi Minh's thought as the guideline for all actions. As a reliable reserve team of the Party, the future owner of the country, each member of the Youth Union is the core nucleus in all activities of the Youth Union, The Vietnamese Youth Association, the Vietnamese Student Association, and the youth movement.

Therefore, studying the activities of the Ho Chi Minh Communist Youth Union has the scientific and practical significance to consult the Party and State in improving the 
implementation of its functions.

\section{Literature Review}

\subsection{The Concept of the Youth, Youth Union and Its Nature}

The youth are a specific social-demographic group consisting of a considerable number of the population from 16 to 30 years old, associated with all classes, and ethnic groups [1]. This is the age of physical and mental development, orientating and growing up. When talking about the position and role of the young K. Marx and F. Engels affirmed: "the Youth is the source and vitality of the nation, and the working class is the body of each nation" [2]. "But anyhow, the enlightened part of the working class is very well aware that the future of their class and therefore the future of all humans, is entirely dependent on the education of the growing working generation [3]. Developing the arguments of K. Marx and F. Engels about the youth in new conditions, V. I. Lenin has considered the youth as "the fighting force of the revolution". As V. I. Lenin affirmed: "The real task of creating communist society is the youth's", [4] i.e. the future of communism belongs to the youth.

Inheriting the precious legacies of K. Marx, F. Engels, and V. I. Lenin, President Ho Chi Minh created Marxist arguments on the role of young people in society, on the task of educating the generation and about the Communist Youth Union in the specific conditions of the Vietnamese revolution. He earnestly called: "Poor Indochina! You will die if your young are old soon and not revived" [5]. He realized that "the youth are an important part of the nation" [6]. The organization of the "Vietnam Youth Revolutionary Union" to prepare for the establishment of the Communist Party of Vietnam and the establishment of the newspaper "Youth" has demonstrated that President Ho Chi Minh has a strategic vision of the youth. In the Testament, he wrote: "Our union members and young people are generally good. Everything is enthusiastically volunteered, not afraid of difficulties, with goodwill to progress. The Party needs to pay attention to educating them on revolutionary morality, training them to be the heirs to build socialism, both "morally" and "professionally". "Fostering the next revolutionary generation is a very important and necessary thing" [7]. The Communist Party of Vietnam affirms that young people have a critical role in the cause of national construction and defense. "Young people are a pioneering force in national construction and defense, one of the decisive factors in the success or failure of the cause of industrialization, national modernization, international integration and socialism building [8]. "The Ho Chi Minh Communist Youth Union is a reliable reserve team of the Party" [9].

The Ho Chi Minh Communist Youth Union is a sociopolitical organization of Vietnamese youth founded, led, and trained by the Communist Party of Vietnam and President Ho Chi Minh. The Youth Union includes advanced youth, striving for the Party's purpose, ideals of national independence associated with socialism, rich people, strong country, democracy, justice, and civilization [10]. The Youth Union is a political-social organization, so this union is political and popular. Politically, the Ho Chi Minh Communist Youth Union was founded, led, and trained by the Vietnamese Communist Party and President Ho Chi Minh. Ho Chi Minh Communist Youth Union used the Party's ideal purpose as its ideal purpose, which is national independence associated with socialism. At the 4th International Congress of Communist Youth in July 1924, Nguyen Ai Quoc drafted a discussion on colonial youth, the thesis affirmed: "Quickly forming youth organizations and building youth unions in colonial countries" [11]. In a letter to the Executive Committee of the Communist Party of Indochina, Nguyen Ai Quoc proposed: "Firstly, the youth organization and the worker union must be unified and those organizations must have their own independent activities" [12].

At the first meeting of the Party Central Committee (October 1930), the Conference passed: "The resolution on the Indochina situation and the necessary tasks of the Party". Especially the meeting passed the "Resolution on the Communist Youth Campaign". The resolution stated: "The Party must immediately implement the Resolution of the International Communist Youth Union and help the Union be independent". "The Communist Party needs to work with the youth masses, and must lead the youth masses". To do so, you can only organize a group of young people. "The central committee, Party committees, provinces, cities, and special commissars have to send many young comrades in charge of organizing the Youth Union and helping the Youth Union to be independent" [13].

The 2nd Party Central Committee Meeting took place in Saigon from March 20 to 26, 1931, chaired by General Secretary Tran Phu. The conference spent a lot of time discussing the work of Party building and building the Youth Union. The conference set out the necessary tasks that the Party must do, including the quick establishment of the Youth Union organization. "it is necessary to organize to the Youth Union, and the Party needs to give up the indifferent attitude towards that issue. Immediately the local Party committees have to quickly organize the members of the Union, the organization cell, and a news agency about the Youth Union's movement and have to direct the newly established branches of the Youth Union to start working among the youth mass. In a short time to come, the local party cells need to found the youth union at the grassroots level" [14]. The Ho Chi Minh Communist Youth Union underwent 7 renaming times according to its historic mission towards the nation: From 1931 to 1936: The Indochinese Communist Youth Union; From 1937 to 1939: Indochinese Democratic Youth Union; From 11/1939 to 1941: Indochinese Anti- Imperialist Youth Union; From 5/1941 - 1956: Vietnamese Youth Union for National Salvation; From October 25, 1956, to 1970: Vietnamese Youth Union; From 2/1970 to 11/1976: Ho Chi Minh Youth Union of Labor; From 12/1976 to present: Ho Chi Minh Communist Youth Union. By the masses, young people are a huge force in society, always accounting for an average of about one-third of the population, so the 
proportion of young people present in all strata of society is very large. However, it must be affirmed that young people have an important position and role in all fields of economy, politics, security, and defense. Wherever there are young people, there is political orientation, helping, consulting, accompanying the youth of the Ho Chi Minh Communist Youth Union; Vietnamese Youth Association, Vietnamese Student Association [15]. The social characteristics of the Youth Union are evident in the activities of the Youth Union, and the Youth's movement. These activities not only spread to union members but also affected young people who were unable to become members. The mass characteristics are also reflected in the fact that the Youth Union is a collective member of the Vietnamese Youth Association, playing a critical role and political orientation for the Association's activities. The Youth Union has a coordinated relationship with socio-political organizations, social and professional organizations to create resources, conditions and contribute to the activities.

\subsection{System Structure, Principles and Functions of the Youth Union}

Regarding the organizational structure system: The organizational structure system of the Delegation includes 4 levels: Central level; Provincial and equivalent level; District level and equivalent; The grassroots level (including the grassroots union and the grassroots branch). The establishment, splitting, merger, consolidation, or dissolution of a Youth Union is decided by the immediate superior union. The Standing Committee of the Central Youth Union shall specify the decentralization in the organizational system of the Youth Union.

In principle: The Ho Chi Minh Communist Youth Union organizes and operates on the principle of democratic centralism. Leadership agencies at all levels of the Union are established by-election, implementing collective leadership and individual responsibility. The highest leading body of the Youth Union is the national congress.

Functions of the Youth Union: From its nature, structure, and principles, the organization of the Ho Chi Minh Communist Youth Union performs three basic functions as follows.

Firstly, The Youth Union is the reliable reserve team, the revolutionary pioneer force of the Communist Party of Vietnam: The Party's reliable reserve team is founded, led, and trained by the Party; absolute loyalty to the Party [16]. The Ho Chi Minh Communist Youth Union takes the lead in implementing the Party's guidelines and State's Laws. The Youth Union is a force involved in building and defending the Party, providing additional cadre- training for the Party.

Secondly, the Youth Union is a socialist school for young people. As a socio-political organization, a socialist school for the youth, the Youth Union creates an environment to help young people promote their impulsive role in all areas of socio-economic life [17]. The Youth Union educated Marxism-Leninism, Ho Chi Minh ideology, guidelines of the Party, policies, and laws of the State for youth union members, thereby enlightening the revolutionary ideal of the Party, the Youth Union, and the nation for young people, to train young cadres and union members to be enthusiastic, qualified, and have political bravery and ideal lives. Third, the Youth Union takes care of and protects the legal rights of youth. The Youth Union creates all necessary conditions, step by step meeting the legitimate needs of material and spiritual life for the union members to help them perform well all their rights and obligations to ensure fairness in study and labor, before the law and public opinion [18]. The youth Union's mission is to encourage the protection and promotion of the positive aspects of youth union members to help them mature in all aspects.

\section{Results and Discussion}

The grassroots youth union organization includes: the grassroots youth union and the grassroots youth branch are established according to residential area, profession, study unit, work, labor, residence, and grassroots unit in People's Armed Forces. Currently, activities of the Ho Chi Minh Communist Youth Union have achieved the following results.

\subsection{In Terms of Education}

Promote learning and follow Ho Chi Minh ideology, morality, and style: Create a strong change in awareness and action among young people. Every year, organize thematic learning among cadres, union members, and youth. Develop and implement the values of criteria and standards in behaviors and lifestyles of young people based on core values of Ho Chi Minh's ideology, morality, and style.

Improve the efficiency of political and ideological education: to attach importance to the propaganda, learning, and application of Marxism-Leninism, Ho Chi Minh's thought, the Party's and the Union's undertakings, lines, and resolutions into working practice and youth life. Renovate the way of propagating, studying, and implementing the resolutions of the Party, Youth Union among the Youth Union members, and the youth. Pay attention to educating and improving political bravery, awareness of revolutionary vigilance for union members and young people.

Implement practical solutions suitable to traditional revolutionary education, patriotism, and national pride for young people: Focus on organizing educational programs and activities widely on the occasion of political events, major holidays of the Party, the nation, the Union, and the Association. Regularly organize gratitude activities, visit historical sites, gratitude activities, care, embellishment, and promote the value of historic sites, cultural relics to educate. system for children.

Strengthen ethical education, cultural lifestyles for young people. Focus on educating compassion, honesty, responsibility; the spirit of fondness for study, love for labor, industrial style in labor; awareness of preserving and promoting national cultural traditions and identity, selectively absorbing the quintessence of human culture.

Implement solutions for law propagation, dissemination, 
and education, forming habits: "Living and working according to the Constitution and the law" among the union members, young people. Choosing contents, reforming propaganda forms on laws and policies related to youth and youth affairs. Focus on propagating and disseminating knowledge of national defense and security, enhancing responsibility, awareness of protecting national sovereignty, national interests, ethnic groups in union members, and the youth. Coordinate with other branches in education, help, and sensitize slow-progressing youth in residential areas.

\subsection{Organize Revolutionary Action Movements to Promote Youth's Role of Pioneering, Volunteering and Creativity in National Construction and Defense}

The first is Youth Volunteers

Volunteer to join hands in building a new lifestyle countryside, mobilize union members and youth to participate in socio-economic infrastructure development; to develop production in association with agricultural restructuring, rural economic restructuring, and apply scientific and technological advances to production and raise incomes; building a cultural life, eliminating rural customs; maintain security and rural social order.

Volunteer to participate in building a civilized city, organizing for union members and young people to build a green, clean, beautiful, and safe urban environment landscape; erase black spots of environmental pollution; ensure social order and safety; building a civilized lifestyle, cultural behavior; participate in building smart cities. Focus on replicating many specialized volunteer squads to coordinate and support functional forces in ensuring social order and safety in the urban area. Volunteer to protect the environment, respond to climate change, implement the program "For a green Vietnam", organize for union members and the youth to plant and protect forests and trees, protect water resources, protect rural, urban, industrial zones, craft villages, river basins, marine environment, and tourist sites.

Volunteer to participate in ensuring traffic order and safety, continue to effectively implement the campaign "the Youth with traffic culture", which focuses on organizing activities to raise awareness of compliance, traffic laws for children. Continue to build and effectively deploy a volunteer team to ensure traffic order and safety. Volunteer to ensure social security, organizing programs and activities associated with the needs of social life. Participate in solving urgent problems, newly arising problems, social security activities, participate in community development, especially support children in difficult circumstances, the elderly, the vulnerable people, relaying to school, taking care of the sick, ensuring food hygiene and safety. Strengthen the organization of volunteer activities in remote and disadvantaged areas.

Second, the creative youth

Be creative in learning and scientific research. Encourage and create an environment for youth union members to propose initiatives and creativity in renewing teaching and learning methods, improving the quality of learning. Research and apprentice scientific research; proactively register to research scientific topics to solve the tasks set out in the process of socio-economic development, ensuring national defense and security. Organize scientific conferences and seminars for young people, students, and young lecturers. Coordinate to organize creative contests for children and teenagers.

Be creative in labor, production, and business, encouraging and promoting the youth to propose initiatives, improve, and apply science and technology to save raw materials, materials, production time; innovate, improve design, design, contribute to improve productivity, quality, increase product value; high-tech agricultural production, clean agriculture; to develop marine, sea and island tourism. Coordinate with organizations, individuals, and enterprises to realize, trade creative ideas, bring innovations, inventions, and inventions into practice; promote innovative start-ups.

Be creative in work, serving the people, union members, and youth should propose initiatives to renovate administrative processes and procedures, improve efficiency and quality of advisory and service work; in training, ready to fight, serving for combat, mastering modern technology and weapons. Organize youth creative technical sports in the country. Renew thinking, methods, and working style.

Creativity in daily life, union members and the youth should propose initiatives and useful solutions to serve the society, improve the quality of life and daily activities. Encourage union members and the youth to research and apply advanced technologies and techniques and propose solutions to participate in solving difficult and pressing problems of the community such as ensuring traffic safety, building new lifestyle rural areas, civilized urban areas, environmental protection, prevention of social evils.

Third, the youth pioneer to defend the homeland

Pioneer in performance of defense and security tasks. Actively propagate and raise awareness and responsibility of union members and the youth in implementing the strategy for national defense in the new situation. Actively fighting to defeat all plans and activities of the hostile forces; prevent and refute false information and claims, increase the youth's resistance to hostile forces; participate in assuring information security and safety, protecting ideological security, cultural security on cyberspace, especially social networks.

Pioneer to participate in the implementation of programs, projects, campaigns towards the border, sea, and islands, protect the sovereignty and territorial integrity. To develop youth volunteering forces in disadvantaged areas, border areas, and islands. Promote the campaign "Love of borders and islands", focusing on effective implementation of the program "Border in March", "Students with sea and islands", "the Youth for the islands of the Fatherland", "building the youth's Island.

Well implement the military rear-wing policy; strengthen activities to help families and relatives of officials and soldiers working in border areas and islands.

Pioneer to participate in building regular and elite revolutionary people's armed forces, step by step modernizing. Effectively implement the movement "the youth of the Army practice virtue, qualification, be creative, 
and win", "the youth of the People's Public Security Forces study and implement 6 things Uncle Ho taught - Pioneering, creativity, volunteering, establishing merit for national security". Launching movements among union members, the youth of the people's armed forces enthusiastically train, strive, take the lead role and act as the core in performing the task of protecting the Fatherland, preserving national security and order. social safety and self; participate in overcoming disaster consequences.

Pioneer to participate in ensuring security and order in residential areas. Continue to effectively implement the movement of the entire people to defend the country. Replicate models of friendship and work coordination between the Youth Union in the armed forces with the Youth Union organization in residential areas, in schools. Improve the quality of activities of volunteers, self-governing youth teams, youth patrol teams, youth watchdogs at the grassroots level. Strengthen the struggle to prevent and combat law violations and social evils, especially drugs among adolescents, to fight against human trafficking and illegal cross-border crossing.

\subsection{Organize Companion Programs with the Youth}

Firstly, accompany with the youth in learning: Build a spirit of fondness for learning, self-study, lifelong learning, a learning society among youth. Organizing activities to support and encourage students to emulate learning; contests and conferences specialized in blocks and disciplines; developing academic clubs among students.

Second, accompany with young people starting a business and setting up a career: Implement effectively the program "Youth start-up". Raising awareness and capacity of union officials at all levels in start-up. Diversify forms of communication about entrepreneurship. Look for, develop and support innovative startup ideas among young people into practice. Consult, train, and support information, knowledge, and skills for young people starting a business. Advise and complete policies to support young people starting their business and participating in economic development.

Third, accompany with young people to practice and develop skills in life, improve physicality, cultural and spiritual life: Propaganda, education to raise awareness, knowledge of skills in life for the youth. Focus on educating on communication skills, behavior, problem solving, criticism, teamwork, foreign language skills, informatics, digital technology, integration skills, improve the positive attitude of the youth in study, labor, and life.

\subsection{The Task of Being in Charge of the Ho Chi Minh Young Pioneers Team and Protecting, Caring for, and Educating Young People and Children}

Raising awareness and responsibility of the Youth Union organization at all levels, especially the district youth union, in charge of the Ho Chi Minh Young Pioneers Organization and protecting, caring for, and educating youth and children. The mission to continue to define building Ho Chi Minh
Young Pioneers Organization is to build Youth Union in advance. Closely coordinate with all levels and branches, take care of building Ho Chi Minh Young Pioneers Organization and children's movement.

\subsection{Youth International Work}

Regarding geographical areas, partners, to prioritize the development of youth cooperation with neighboring countries, ASEAN, and countries that have an important position in the foreign policy of the Party, State, organizations, and multicooperation mechanisms of which Vietnam is a member; strengthening traditional friend relationships; promote a responsible role in the activities of the World Youth Union and the progressive and peace-loving forces. Actively establish relationships with youth organizations belonging to the parties having relations with our Party.

In the field of cooperation, priority is given to expanding and promoting cooperation in the fields of youth development (training young leaders, active citizens, global citizens); environment and sustainable development; volunteer for the community; creative startups; social enterprise development.

Support union members and young people in international integration, propaganda, mobilize union members, young people to be active in research, study, and training to be ready for integration. Promote propaganda about international situation, international and global issues for union members and youth.

\subsection{Union Building Work, Expanding Solidarity Front for Youth Gathering}

Youth union building work at the grassroots levels.

Develop and implement breakthrough solutions in improving the quality of Youth Unions at the grassroots level. Focus on researching, synthesizing, and building solutions to promptly remove difficulties, problems, and shortcomings in the operation mechanism, union cadres work in specific areas and residential areas. The work of expanding the solidarity front, gathering young people: Promoting the key political role of the Ho Chi Minh Communist Youth Union in the Vietnam Youth Association, the Vietnam Student Association, and the collective member organizations of the Vietnam Youth Association. Gather, orient, and guide youth movement activities. Strongly promote the role of the Vietnam Youth Association, Vietnam Student Association in gathering the youth and additional resources for the Youth Union. To consolidate the organization and reorganize activities of the Association at district and grassroots levels.

\subsection{The Youth Union Participated in Building and Defending the Party and the Political System}

Participating in building and defending the Party and the political system is the responsibility and political interests of the Youth Union members, the youth, and the Youth Union organization, and is a regular important task of all levels of the Union. 
Propagate, grasp, and implement the Party's undertakings, the State's policies and laws; promote education to raise awareness of political and ideology for union members and youth about the Party; fight to protect the political platform, the Party's line. Organize for cadres, union members, and young people to contribute suggestions on Party building, government construction, prevention of corruption, waste, Party members' suggestions, prevention of moral degradation, lifestyle, "self-development", "internal self-transformation" with appropriate form. Effectively coordinate and implement Joint Resolution on the Regulation on coordination between the Government and the Central Committee of the Youth Union, between the People's Committee and the Executive Committee at all levels, and programs to coordinate with other agencies. ministries, branches, socio-economic organizations in youth education, fostering, care, and promotion.

\section{Conclusion}

Unlike previous generations of young people, today's young generation in our country inherits a great happiness of living in independence and freedom, living, studying, working, and fighting with clear goals. That goal is the lofty ideal of the era, socialism, and communism. The Ho Chi Minh Communist Youth Union at the grassroots level plays an important role in bringing together youth and union members to accomplish this goal. Therefore, it is possible to come to the conclusions that have met the objectives as well as the initial research hypotheses that the study aims, specifically as follows:

1 / The study has clarified the concepts of the youth and the Ho Chi Minh Communist Youth Union in Vietnam today. This is a political-social position under the leadership of the Communist Party of Vietnam to implement the Party's objectives.

2 / The study has shown the current status of the Youth union's activities in 7 issues that youth union at the grassroots level is implementing (3. Results and discussion). It shows the specific role and duties of the Ho Chi Minh Communist Youth Union at the grassroots level of organizing activities to educate and train union members and the youth; represent, care for and protect the legal and legitimate rights and interests of cadres, union members and young people. Coordinate with the authorities, unions, and socio-economic organizations to do well the youth work, take care of the Youth Union building, protect the Party and the government.

Our Youth union members and the youth from generation to generation always promote their role as pioneers, always strive for the cause of fighting for national independence, as well as in the socialism building industry and national defense. At the same time, it has built the organization of the youth union at the grassroots level to become stronger and stronger, worthy of being a powerful assistant and a strong back force of the Party.

\section{References}

[1] Youth Law (2005).

[2] K. Marx and F. Engels (1982). Talking about youth. Hanoi: Youth Publishing House, p. 82.

[3] K. Marx and F. Engels (1982). Talking about youth. Hanoi: Youth Publishing House, p. 101

[4] V. I. Lenin (1983). Complete Works, Vol. 31, Moscow: Progressive Publishing House, p. 30.

[5] Ho Chi Minh (1995). Complete works. Vol. 2, Hanoi: National Political Publishing, p. 133.

[6] Ho Chi Minh (1995). Complete works, Vol. 7. Hanoi: National Political Publishing House, p. 398.

[7] Testament of President Ho Chi Minh.

[8] The Communist Party of Vietnam: Resolution No. 25-NQ / TW, the Seventh Conference of the Central Committee, term $X$ on strengthening the Party's leadership in youth work in the period of accelerating industrialization and modernization.

[9] Central Propaganda Department (2016). Document for fostering Party Secretaries and grassroots Commissioners, Hanoi: Publisher National Politics Truth.

[10] The Charter of the Delegation affirms (through the XI National Congress of the Ho Chi Minh Communist Youth Union passed on December 13, 2017).

[11] Ho Chi Minh (2000). Complete Works. Vol. 10, Hanoi: National Political Publishing House, p. 21.

[12] Ho Chi Minh (2002). Complete Works. Vol. 3, Hanoi: National Political Publishing House, p. 75.

[13] Communist Party of Vietnam: Document of the Party. Complete works. Vol. 3, p. 91.

[14] Communist Party of Vietnam: Document of the Party. Complete works. Vol. 3, pp. 98-99.

[15] Central Propaganda Department (2006). Lecture on mass mobilization, Hanoi: National Politics Publishing House.

[16] Ho Chi Minh National Academy of Politics (2018). Curriculum on professional work of the Fatherland Front and the People's Union at the grassroots level. Hanoi: Political Theory Publisher.

[17] Political-Administrative Academy Region I (2013): Textbook of Party's mass mobilization in new situation. Hanoi: Politics - Administration Publishing House.

[18] Central Propaganda Department (2007). The handbook on mass mobilization work. Hanoi: National political publishing house. 